\title{
Short Communication: \\ Use of Geographic Information System for mapping of Aquilaria malaccensis land suitability in North Sumatra, Indonesia
}

\author{
RAHMAWATY ${ }^{1}{ }^{1}$, , SINTIKE FRASTIKA ${ }^{1}$, RUTH MARIA ELTIANA MARPAUNG ${ }^{1}$, \\ RIDWANTI BATUBARA ${ }^{1}$, ABDUL RAUF ${ }^{2}$ \\ ${ }^{1}$ Faculty of Forestry, Universitas Sumatera Utara. Jl. Tridharma Ujung No.1, Kampus USU Padang Bulan, Medan 20155, North Sumatra, Indonesia. \\ Tel./fax.: +62-61 8220605/+62-61 8201920. •email: rahmawaty@usu.ac.id \\ ${ }^{2}$ Faculty of Agriculture, Universitas Sumatera Utara. Jl. Dr. A. Sofian No.3, Kampus USU Padang Bulan, Medan 20155, North Sumatra, Indonesia
}

Manuscript received: 4 July 2019. Revision accepted: 20 August 2019.

\begin{abstract}
Rahmawaty, Frastika S, Marpaung RME, Batubara R, Rauf A. 2019. Short Communication: Use of Geographic Information System for mapping of Aquilaria malaccensis land suitability in North Sumatra, Indonesia. Biodiversitas 20: 2561-2568. The Geographic Information System (GIS) can be applicated in the field of forestry and agriculture, such as for mapping as part of land evaluation. The land suitability of Aquilaria malaccensis in the agroforestry land of North Sumatra Province is important. Commonly, A. malaccensis were planted by the community in Langkat and Deli Serdang District. This study aimed to map the land suitability for $A$. malaccensis in Telaga Village, Sei Bingai Sub District, Langkat District, Peria-ria Village and Sari Laba Jahe Village, Biru-biru Sub District, Deli Serdang District. A survey method was used to collect soil samples in the field. Land suitability classification (LSC) for A. malaccensis was evaluated based on the matching method. The results showed that the actual land suitability classes for A. malaccensis in Telaga Village were moderately suitable (S2) and marginally suitable (S3). The actual land suitability classes for A. malaccensis in Peria-ria Village and Sari Laba Jahe Village were moderately suitable (S2), marginally suitable (S3) and not suitable (N). There were several limiting factors in land suitability evaluation in the area, namely: nutrient retention (nr), erosion hazard (eh), and root zone medium (rc).
\end{abstract}

Keywords: Agarwood, Aquilaria malaccensis, GIS, land suitability

\section{INTRODUCTION}

Geographical Information System (GIS) has been widely applied in various fields, including forestry and agriculture. According to Rahmawaty et al. (2012), Rahmawaty et al. (2014), Rahmawaty et al. (2017a), Rahmawaty et al. (2017b), Rahmawaty et al. (2018), Rahmawaty et al. (2019a), Satriawan et al. 2015, one application of GIS in the field of forestry and agriculture is mapping of land evaluation and presenting the results in the form of maps. The Geographical Information System (GIS) is used for data collection, storage, analysis and manipulation of geographic references, include layout the map to show the spatial distribution of geographical phenomena including characteristics that are in accordance with those on the surface of the earth (Rahmawaty et al. 2011).

Aquilaria malaccensis in Langkat District, was planted by community on the sidelines of old rubber and oil palm plants (Rahmawaty and Rauf 2012). A. malaccensis is one of the agarwood-producing trees, spread in Sumatra, Java, Kalimantan, Sulawesi, Maluku, Papua and Nusa Tenggara (Surjanto et al. 2019). Agarwood includes non-timber forest products, is a resin that was obtained from microbial infections result of the family Thymeleacea, Leguminoceae, and Euphorbiaceae. Among several agarwood types of there are 3 (three) types of good quality, namely: A. malaccensis, Aquilaria filarial and Aetoxylon sympethallum (Surjanto et al. 2019; Usuluddin et al. 2018). According to Usuluddin et al. (2018), one of the factors that causes limited agarwood yield from plantations, because planting can only be done in the shade, its nature was semi tolerant, causing people to not be able to plant $A$. malaccensis in open land including former cultivation, exfires and other non-productive areas that were open. A. malaccensis are favorite plants and very popular for people in North Sumatra, especially in the agroforestry land because of their high economic value.

Land evaluation is a process of assessing the potential of land for certain uses. Land suitability is the suitability of land for certain uses (Arsyad 2010; Rahmawaty et al. 2011; Rahmawaty et al. 2016). Land evaluation results are used as a basis for rational land use planning, so that land can be used optimally and sustainably (Ritung et al. 2011). The land evaluation process for A. malaccensis is carried out by comparing the growth requirements of $A$. malaccensis species to the characteristics of the land. Land suitability evaluation needs to be done to be a basis for consideration in land use decision making (Ritung et al. 2011). Further, according to FAO (1976), Arsyad (2010), distinguishes land suitability into two classes, namely: actual land suitability class and potential land suitability class. The actual land suitability (current land suitability of land in its natural state) is not considered to repair business and management level that can be done limiting factors. 
The limiting factors can be divided into two types, namely: permanent (impossible or uneconomical to repair) and can be improved and still economically profitable. For instance, by incorporating the right technology.

Land evaluation results can be described in the form of maps using Geographic Information System (GIS) technology. Geographic Information System technology is very helpful in various research topics including research related to vegetation and the most popular tool used for studying the vegetation cover of a particular area. Several researches have proved that GIS can be an impressive instrument for cataloging vegetation data obtained from ground surveys into mapping and analysis. For instance, Rahmawaty et al. (2019b), Rahmawaty et al. (2012), Harahap et al. (2019) have been using GIS mapping of actual and potential land suitability for oil palm. Rahmawaty et al. (2019c), have been using GIS for spatial analysis of Pinus merkusii land suitability. Piri et al. (2019) used GIS to assess the suitable areas for medicinal plant species of Astragalus. Rahmawaty et al. (2019a) have used GIS for mapping of medicinal plants in Deli Serdang District. Shojaeic et al. (2018) have been used GIS on locating Astragalus hypsogeton Bunge appropriate site. Rahmawaty et al. (2016) have been used GIS for land suitability for Tectona grandis: case study in Arboretum Kwala Bekala, Sumatera Utara University. Satriawan et al. (2015) have been used GIS for soil conservation to erosion control on several land-use types. Satriawan et al. (2014) have been used GIS for Land capability evaluation for agriculture in Krueng Sieumpo Watershed.

As listed in the Appendix II of CITES (2014), A. malaccensis is categorized an endangered tree species. Study about $A$. malaccensis have been conducted by some researcher, such as: Borah et al. (2012) have been studied about new record of leaf spot disease on A. malaccensis Lamk. in India, Shankar (2012) has been studied about effect of seed abortion and seed storage on germination and seedling growth in A. malaccensis, Singh et al. (2015) have been studied about development and characterization of polymorphic microsatellites markers in endangered $A$. malaccensis and genetic diversity and population structure of endangered A. malaccensis, Siah et al. (2016) have been studied about transcriptome reveals senescing callus tissue of A. malaccensis, an endangered tropical tree, triggers similar response as wounding with respect to terpenoid biosynthesis, Wong et al. (2013) have been studied about characterization of wound responsive genes in $A$. Malaccensis, Putri et al. (2017) have been studied about evaluation of incense-resinous wood formation in agarwood using sonic tomography and Usuluddin et al. (2018), have been studied about the growth of $A$. malaccensis in alluvial soils with different shade and height of seedlings. Research of mapping of land suitability for $A$. malaccensis in this location has never been conducted, even though, Sei Bingai Sub District, Langkat District, and Biru-biru Sub District, Deli Serdang District, North Sumatera Province are potential location to develop $A$. malaccensis in North Sumatra Province. Based on the description above, assessment of the land suitability both the actual and potential land suitability classes for $A$. malaccensis in North Sumatra Province is needed. There is a lack of research related distribution of A. malaccensis land suitability in North Sumatra Province, there is a lack of data and information on the actual and potential land suitability in Langkat District and Biru-biru District. Therefore, this study aimed to evaluate the potential location development of smallholder A. malaccensis in North Sumatra Province based on aspects physically in Telaga Village, Sei Bingei Sub District, Langkat District and Peria-ria Village and Sari Laba Jahe Village, Biru-biru Sub District, Deli Serdang District, North Sumatra. The results of the study are expected to be input to local governments in policy formulation development of smallholder A. malaccensis plantations in North Sumatra Province, especially in the Langkat District and Deli Serdang District, North Sumatra Province, Indonesia.

\section{MATERIALS AND METHODS}

\section{Study area}

This research was conducted in Telaga Village, Sei Bingai Sub District, Langkat District (Figure 1), Peria-ria Village and Sari Laba Jahe Village of Biru-biru Sub District, Deli Serdang District (Figure 2). Both districts in North Sumatra Province, Indonesia. This research was conducted during January to Juni 2019.

\section{Data collection}

A survey method was conducted to collect soil samples in the field. Primary data were obtained from field survey and soil samples were analyzed in the laboratory. Secondary data were obtained from literature and some institution, such as: the rainfall data from the meteorology, climatology and geophysics agency. Land suitability evaluation was done by comparing the characteristics of land with the requirements of growing A. malaccensis. The process of evaluating the suitability of land through matching between land characteristics and growth requirements of $A$. malaccensis species in order to obtain land suitability classes. Results of assessment of land suitability class were based on matching methods (Rahmawaty et al. 2011; Ritung et al. 2011). The actual land suitability is the land suitability classes based on survey data from the field to the area of research and effort has been no improvement while considering the suitability of potential land is land suitability achieved after the improvement efforts carried out (Arsyad, 2010).

\section{Data analysis}

Land suitability classification (LSC) was evaluated based on the matching method (Ritung et al. 2011). The reference and criteria were adopted from the Land Suitability for Agricultural Plants by the Centre for Soil and Agroclimate Research, Bogor-Indonesia (Ritung et al. 2011); (Soil Research Center, 2003). The land quality and characteristics are temperature (tc), water availability (wa) (annual rainfall), oxygen availability (oa) (drainage), root zone medium (rc) (texture, soil depth), nutrients retention (nr) (cation exchange capacity, base saturation, $\mathrm{pH}, \mathrm{C}-$ organic), sodicity (alkalinity), erosion hazard (slope, soil erosion), and flood hazard (fh) (inundation). 

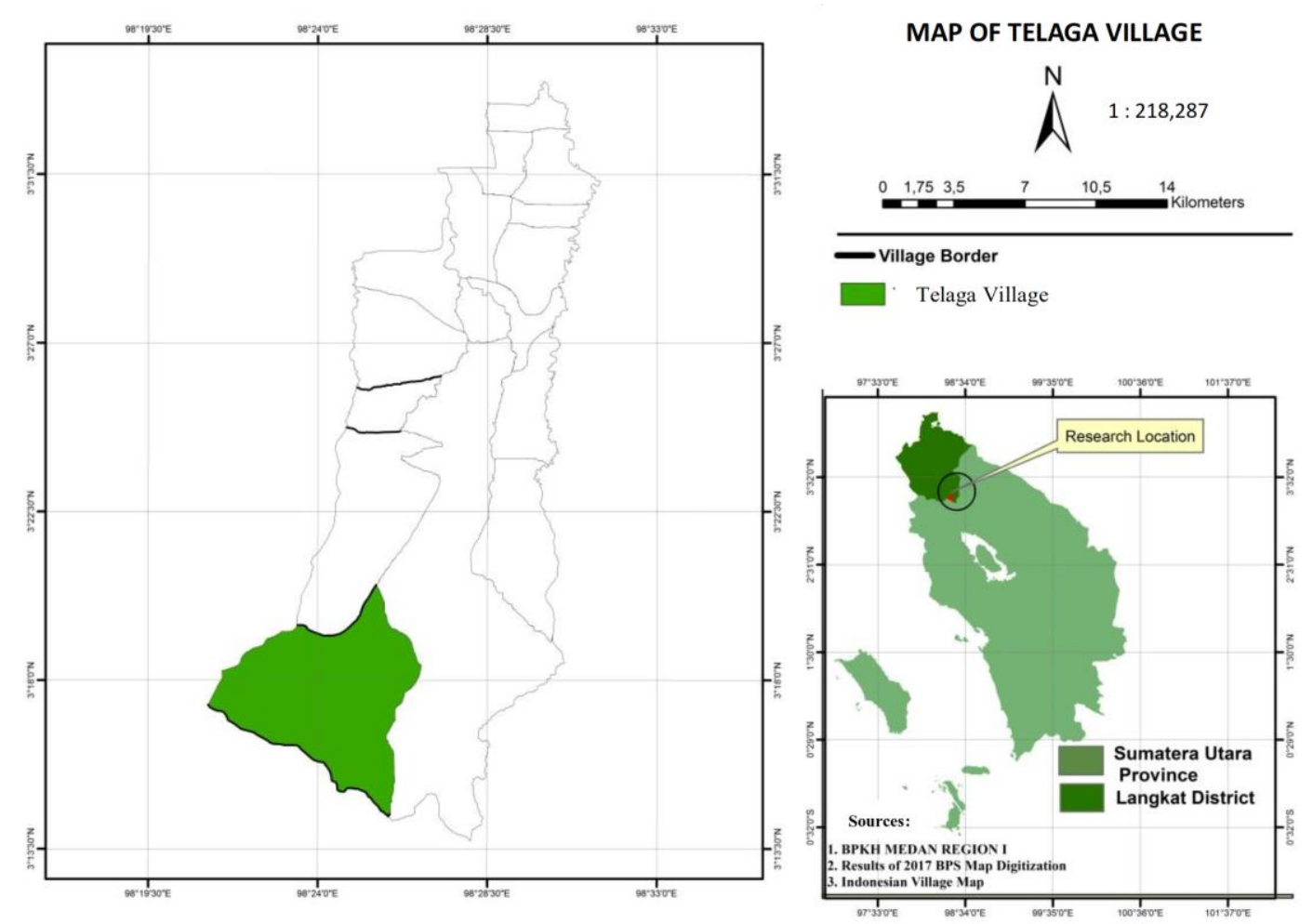

Figure 1. Map of research location in Telaga Village, Sei Bingai Sub District, Langkat District, North Sumatra Province, Indonesia
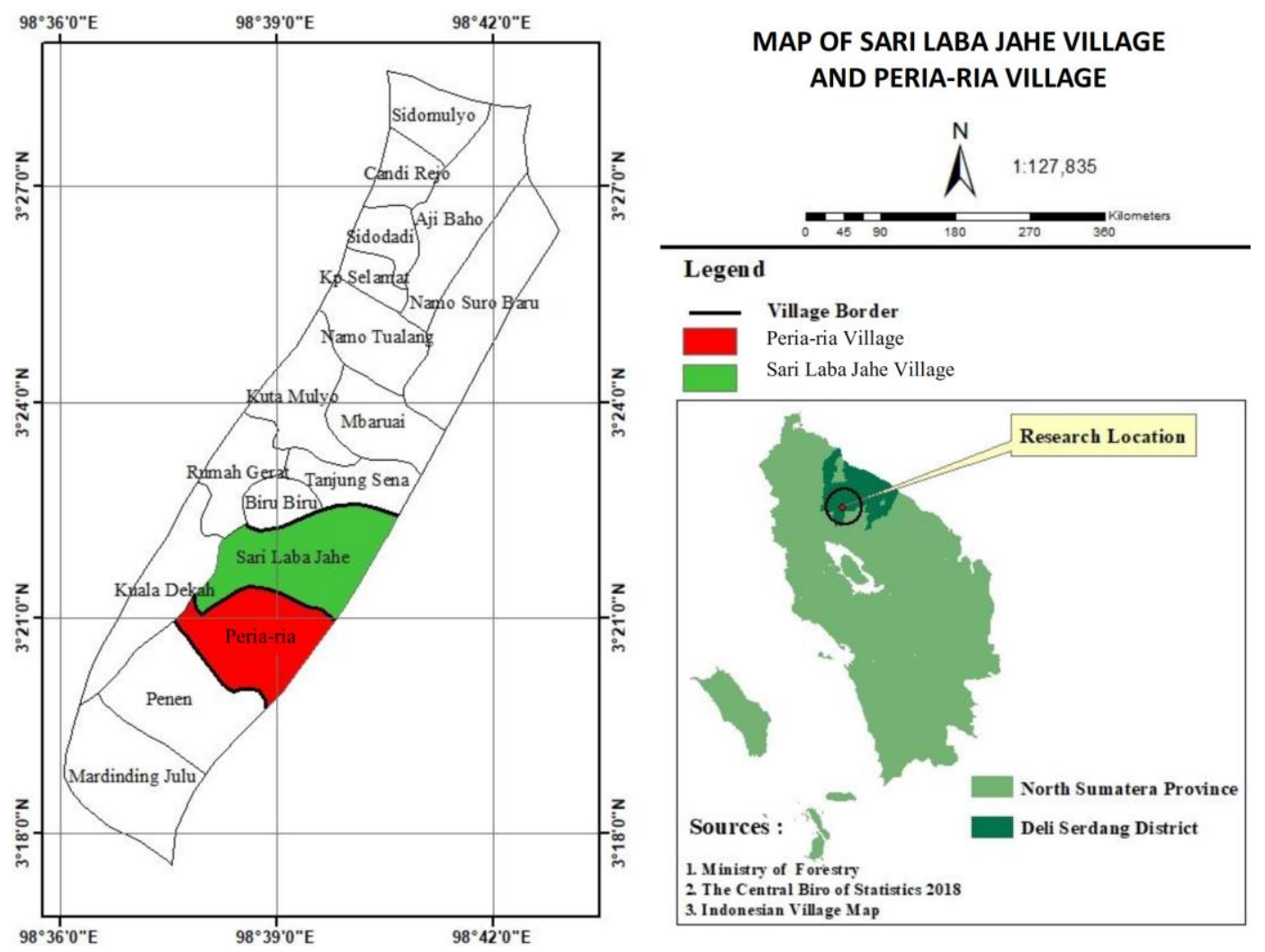

Figure 2. Map of research location in Peria-ria Village and Sari Laba Jahe Village, Biru-biru Sub District, Deli Serdang District, North Sumatra Province, Indonesia 
The GIS was used to map the land suitability classes (actual and potential). The results of the assessment of the actual and potential land suitability classes were presented in the form of tables and maps that provide a class description of the land suitability of A. malaccensis for assessed. The land suitability ratings have been defined by FAO (1976) for international use. The assessment and presentation of land suitability class results were based on FAO (1976); namely: highly suitable (S1) means that land having no significant limitations to sustain application of a given use or only minor limitations that will not significantly raise inputs above and acceptable level, moderately suitable (S2) means that land having limitations that in aggregate are moderately severe for sustained application of given use. The limitation will reduce productivity and increase required inputs, marginally suitable (S3) means that lands having limitations, which are severe for sustained application of a given use and will so reduce productivity or benefits or increase required inputs that this expenditure will be only marginally justified, not suitable (N1) means that currently not suitable, and not suitable (N2) means that permanently not suitable.

\section{RESULTS AND DISCUSSION}

\section{Land suitability for Aquilaria malaccensis in Telaga Village}

The actual land suitability classes for A. malaccensis in Telaga Village is presented in Table 1 and Figure 3.

Based on Tabel 1 and Figure 1, actual land suitability classes for A. malaccensis in Telaga Village was moderately suitable (S2), with area of $4,321.5$ ha $(92.83 \%)$ from the total area and limiting factor were nutrients retention (nr), root zone medium (rc), and erosion hazard (eh), followed by marginal suitable (S3) with area of 333.95 ha $(7.17 \%)$ with limiting factor was rc and eh. Nutrients retention (nr), can be improved by fertilization (organic and inorganic) such as by urea and superphosphate fertilizers. The slope (eh) can be improved by terracing steep areas. The most difficult constraint to counter were root zone medium (rc), because they were natural limitations. Hence, potential land suitability classes for $A$. malaccensis in the area could become highly suitable (S1), S2 and S3 (Table 2 and Figure 4). There were no not suitable $(\mathrm{N})$ classes were found in the Telaga Village, in accordance with the work of Rahmawaty et al. (2019a).

\section{Land suitability for Aquilaria malaccensis in Peria-ria Village and Sari Laba Jahe Village}

The actual land suitability classes for A. malaccensis in Peria-ria Village and Sari Laba Jahe Village are presented in Table 3 and Figure 5.

Based on Tabel 3, actual land suitability for $A$. malaccensis in Peria-ria Village and Sari Laba Jahe Village was moderately suitable (S2), with area of 19.50 ha $(1.22 \%)$ from the total area and limiting factor were nutrients retention (nr) and root zone medium (rc), followed by marginal suitable (S3) with area of 131.37 ha
$(8.25 \%)$ from the total area and limiting factor was root zone medium $(\mathrm{rc})$ and not suitable $(\mathrm{N})$ classes with area of $1,442.53$ ha $(90.54 \%)$ from the total area and limiting factor was root zone medium (rc) and erosion hazard (eh). According to Rahmawaty et al. (2019a), class S3 means that lands having limitations, which are severe for sustained application of a given use and will so reduce productivity or benefits or increase required inputs that this expenditure will be only marginally justified. The slope (eh) can be improved by terracing steep areas. As mention above, the most difficult constraint to counter were root zone medium (rc) because they were natural limitations. Hence, potential land suitability for A. malaccensis in Peria-ria Village and Sari Laba Jahe Village could become S2rc (19.50 ha), S3rc (131.37 ha), S3rc,eh (1230.08 ha) and Nrc (212.45 ha) (Tabel 4 and Figure 6). Based on Table 4, there were no highly suitable (S1) classes were found in the area in accordance with the study research of Rahmawaty et al. (2019b), Rahmawaty et al. (2015).

The comparison area of actual and potential land suitability classes for A. malaccensis in Telaga Village, Peria-ria Village and Sariaba Jahe Village are presented in Figure 1, Figure 2, Figure 3 and Figure 6. To overcome the limiting factor on $\mathrm{S} 3$, is required high capital so that the need for assistance or intervention (investment) by government or company. For the corresponding marginal suitable land (S3) with a rather severe limiting factor, namely nutrient retention (nr) especially highly acidic soil reaction, extremely low base saturation and high aluminum poisoning hazard. Improved management of land necessary to improve the productivity of the soil are: (i) the addition of soil organic matter to improve soil CEC and the availability of $\mathrm{N}$ and $\mathrm{P}$, (ii) balanced fertilization, especially $\mathrm{P}$ and (3) provision of agricultural lime (Rahmawaty et al. 2011), (Arsyad, 2010).

Table 1. The actual land suitability for Aquilaria malaccensis in Telaga Village, North Sumatra, Indonesia

\begin{tabular}{lcc}
\hline \multirow{2}{*}{ Actual land suitability } & \multicolumn{2}{c}{ Area } \\
\cline { 2 - 3 } & Ha & \% \\
\hline S2,nr,eh & $2,422.70$ & 52.04 \\
S2,rc,nr,eh & $1,898.80$ & 40.79 \\
S3,rc,eh & 38.22 & 0.82 \\
S3,rc & 295.73 & 6.35 \\
Total & $4,655.45$ & 100.00 \\
\hline
\end{tabular}

Table 2. The potential land suitability for Aquilaria malaccensis in Telaga Village, North Sumatra, Indonesia

\begin{tabular}{lcc}
\hline \multirow{2}{*}{ Potential land suitability } & \multicolumn{2}{c}{ Area } \\
\cline { 2 - 3 } & Ha & \% \\
\hline S1 & $2,422.70$ & 52.04 \\
S2,rc & $1,898.80$ & 40.79 \\
S3,rc & 333.95 & 7.17 \\
Total & $4,655.45$ & 100.00 \\
\hline
\end{tabular}




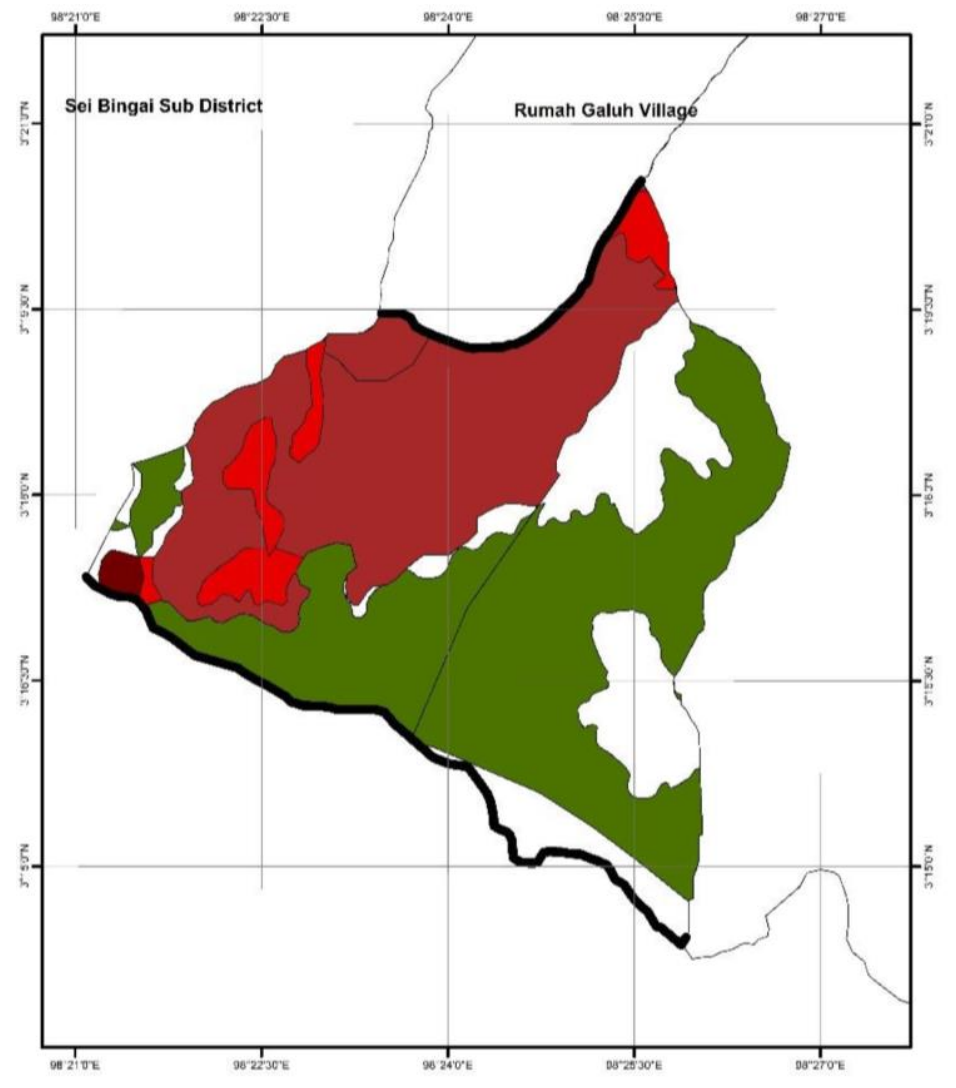

ACTUAL LAND SUITABILITY MAP FOR Aquilaria malaccensis in Telaga Village
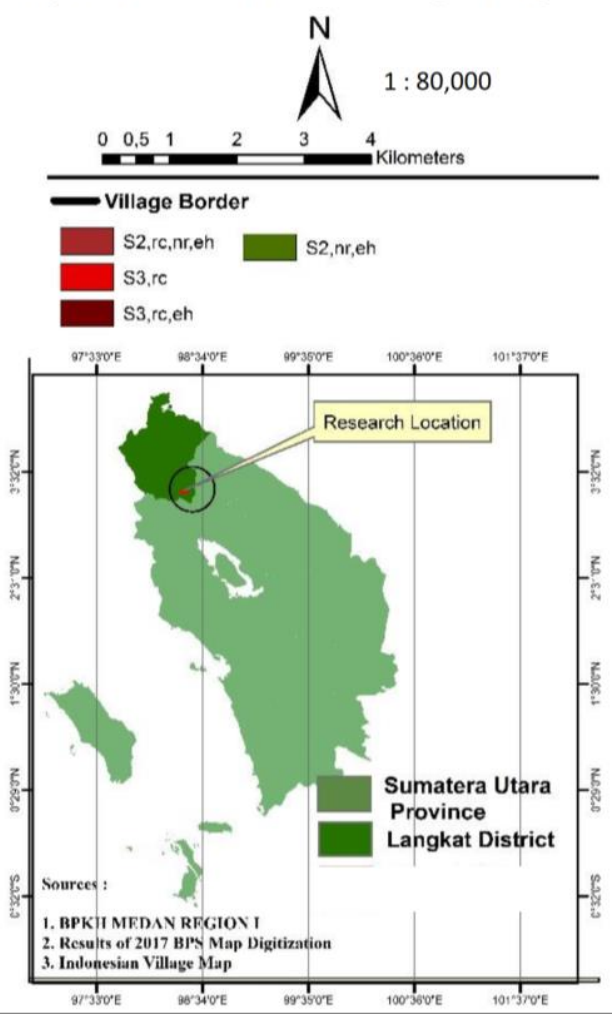

Figure 3. Distribution map of actual land suitability for Aquilaria malaccensis in Telaga Village, North Sumatra, Indonesia

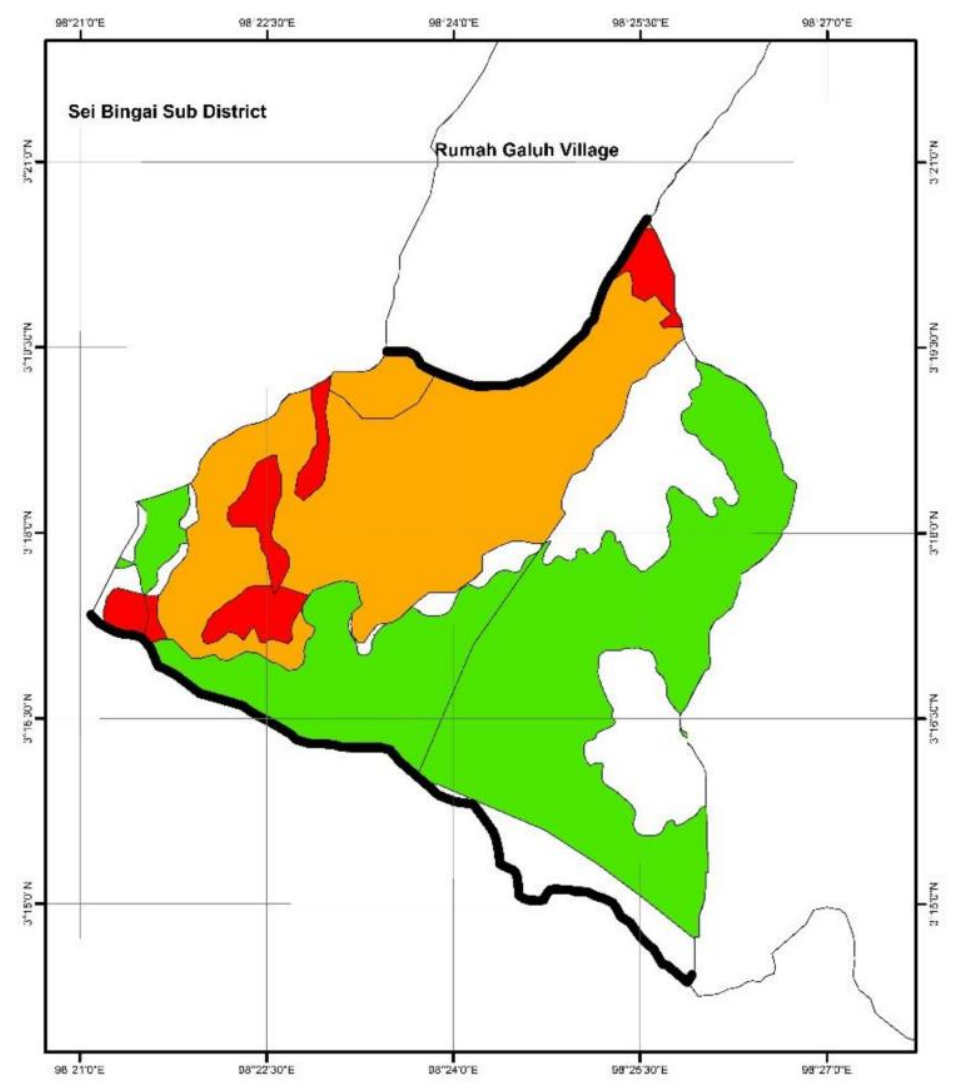

POTENTIAL LAND SUITABILITY MAP FOR Aquilaria malaccensis in Telaga Village
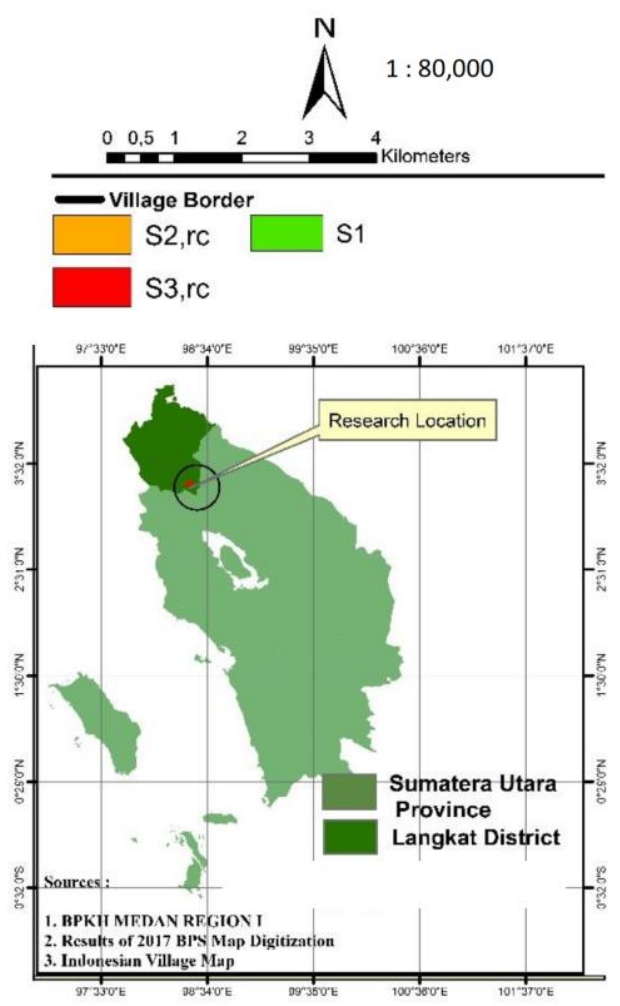

Figure 4. Distribution map of potential land suitability for Aquilaria malaccensis in Telaga Village, North Sumatra, Indonesia 


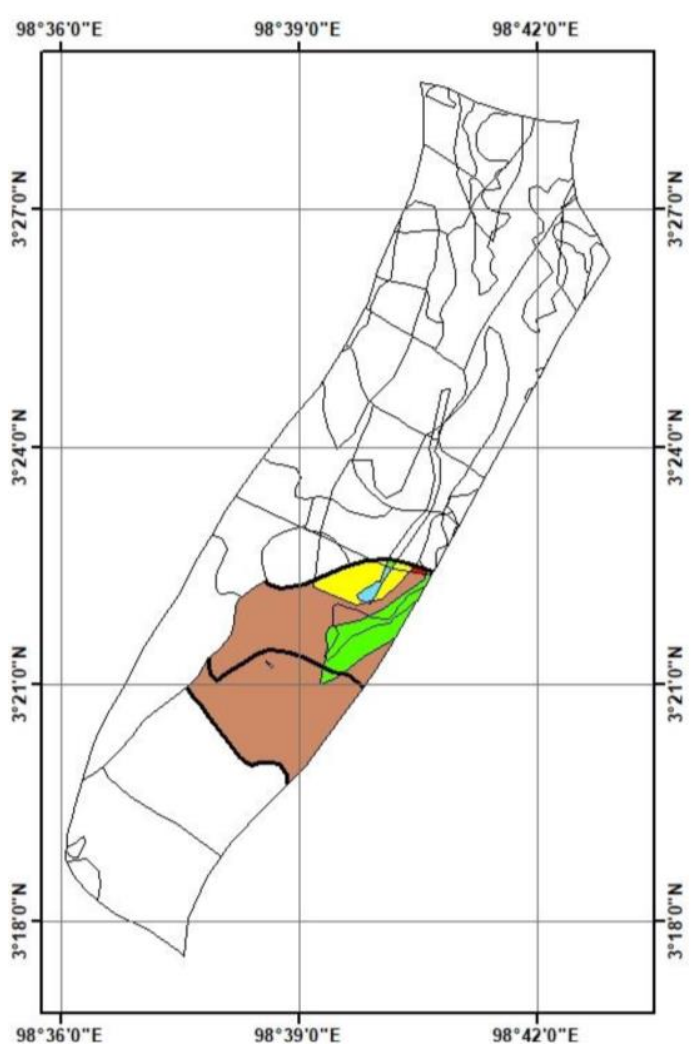

\section{ACTUAL LAND SUITABILITY MAP FOR Aquilaria malaccensis} in Peria-ria Village \& Sari Laba Jahe Village

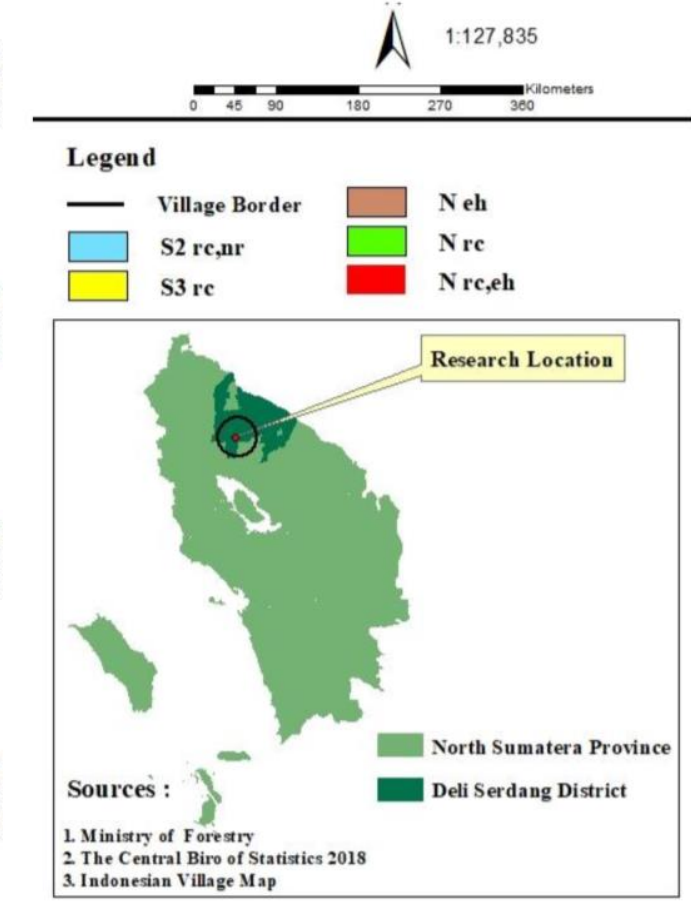

Figure 5. Distribution map of actual land suitability for Aquilaria malaccensis in Peria-ria Village and Sari Laba Jahe Village, North Sumatra, Indonesia

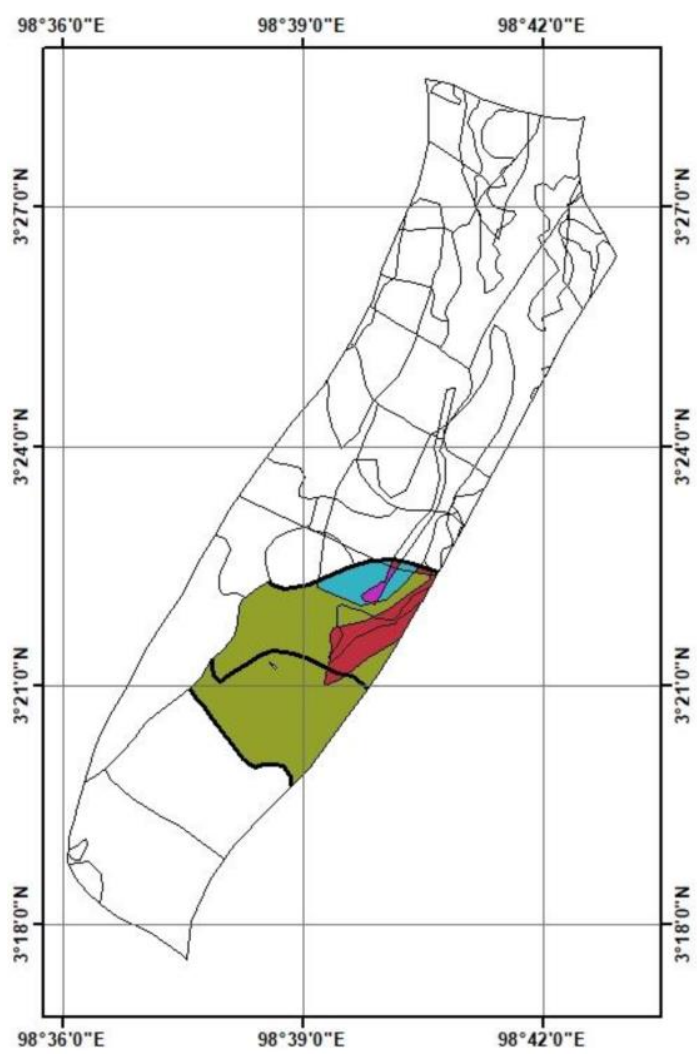
POTENTIAL LAND SUITABILITY MAP FOR Aquilaria malaccensis

in Peria-ria Village \& Sari Laba Jahe Village
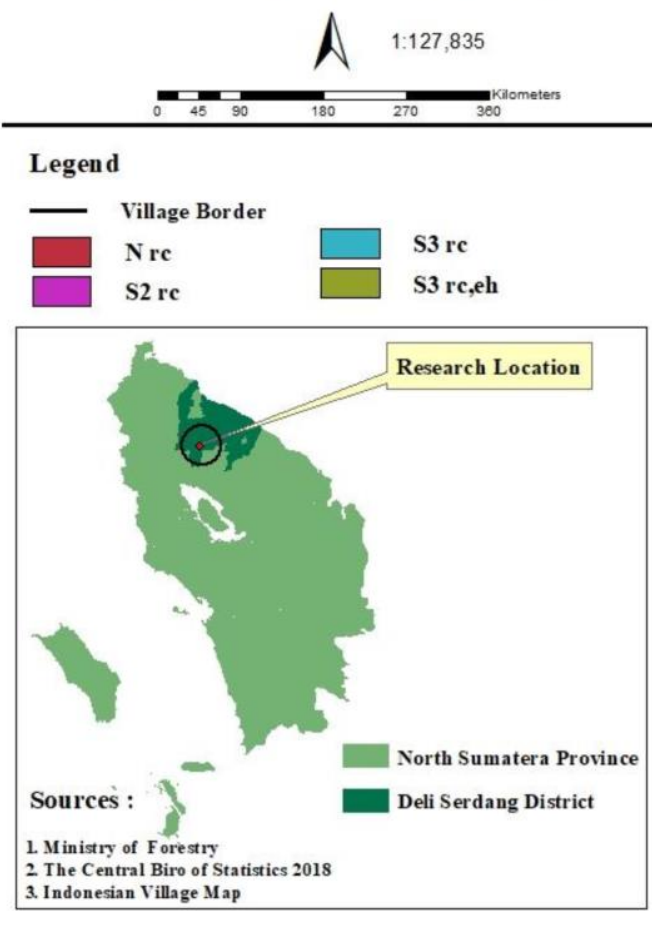

Figure 6. Distribution map of potential land suitability for Aquilaria malaccensis in Peria-ria Village and Sari Laba Jahe Village, North Sumatra, Indonesia 
Table 3. The actual land suitability for Aquilaria malaccensis in Peria-ria Village and Sari Laba Jahe Village, North Sumatra, Indonesia

\begin{tabular}{lcc}
\hline \multirow{2}{*}{ Actual land suitability } & \multicolumn{2}{c}{ Area } \\
\cline { 2 - 3 } & Ha & \% \\
\hline S2 rc,nr & 19.50 & 1.22 \\
S3 rc & 131.37 & 8.25 \\
N rc & 207.70 & 13.04 \\
N eh & $1,230.08$ & 77.20 \\
N rc,eh & 4.75 & 0.30 \\
Total & $1,593.40$ & 100.00 \\
\hline
\end{tabular}

Table 4. The potential land suitability classes for Aquilaria malaccensis in Peria-ria Village and Sari Laba Jahe Village, North Sumatra, Indonesia

\begin{tabular}{lcc}
\hline \multirow{2}{*}{ Potential land suitability } & \multicolumn{2}{c}{ Area } \\
\cline { 2 - 3 } & Ha & \% \\
\hline N rc & 212.45 & 13.33 \\
S3 rc,eh & $1,230.08$ & 77.20 \\
S3 rc & 131.37 & 8.25 \\
S2 rc & 19.50 & 1.22 \\
Total & $1.593,40$ & 100.00 \\
\hline
\end{tabular}

In conclusion, based on potential land suitability class, $52.04 \%$ from total area highly suitable, $40.79 \%$ moderately suitable and only $7.17 \%$ marginally suitable for $A$. malaccensis in Telaga Village. In Peria-ria Village and Sari Laba Jahe Village, only $1.22 \%$ from total area moderately suitable, $85.45 \%$ marginally suitable and $13.33 \%$ not suitable. The root zone medium (rc) was limiting factors in Telaga Village, Peria-ria Village and Sari Laba Jahe Village.

\section{ACKNOWLEDGMENTS}

This work was part of a research project about mapping of multipurpose tree species (MPTS) and agarwoodproducing trees (Aquilaria malaccensis) land suitability on three types of land cover in North Sumatera, funded by Universitas Sumatera Utara (USU) based on TALENTA USU Research Contract Number: 4167/UN5.1.R/PPM/2019 on April 1 1st, 2019.

\section{REFERENCES}

Arsyad S. 2010. Soil and water conservation. $2^{\text {nd }}$ ed. IPB Press, Bogor [Indonesian]

Borah RK, Ahmed FS, Sarmah GS, Gogoi B. 2012. A new record of leaf spot disease on Aquilaria malaccensis Lamk. in India. Asian J. Plant Pathol. 6: 48-51.

CITES. 2014. Appendix II of convention on international trade in endangered species of wild fauna and flora. http://www.cites. org/eng/app/appendices.php

Food and Agriculture Organization (FAO). 1976. A Framework for Land Evaluation. FAO Soil Bulletin 32. FAO, Rome. Italy.

Harahap FS, Sitompul R, Rauf A, Rahmawaty, Harahap DE, Walida H. 2019. Land suitability evaluation for oil palm plantations (Elaeis guineensis Jacq.) on Sitellu Tali Urang Julu, Pakpak Bharat District. IOP Conf. Ser.: Earth Environ. Sci. 260: 012116. DOI: 10.1088/1755$1315 / 260 / 1 / 012116$

Putri N, Karlinasari L, Turjaman M, Wahyudi I, Nandika D. 2017. Evaluation of incense-resinous wood formation in agarwood (Aquilaria malaccensis Lam.) using sonic tomography. Agric Nat Res 51. DOI: 10.1016/j.anres.2016.08.009.

Piri I, Moosavi M, Taheri AZ, Alipur H, Shojaei S, Mousavi SA. 2019. The spatial assessment of suitable areas for medicinal species of Astragalus (Astragalus hypsogeton Bunge) using the Analytic Hierarchy Process (AHP) and Geographic Information System (GIS). Egypt J Rem Sens Space Sci. DOI: 10.1016/j.ejrs.2018.02.003

Rahmawaty, Villanueva TR, Carandang MG. 2011. Participatory land-use allocation, case study in Besitang Watershed, Langkat North Sumatra, Indonesia. Lambert Academic Publishing, Germany.

Rahmawaty, Villanueva TR, Carandang MG, Lapitan RL, Bantayan NC, Alcantara AJ. 2012. Land suitability for oil palm in Besitang watershed, north Sumatra, Indonesia. Science Journal of Agricultural Research and Management, 2012. DOI: 10.7237/sjarm/124

Rahmawaty, Rauf A. 2012. Utilization of land in old rubber plantation at Gunung Leuser National Park, Indonesia. Sci J Agric Res Manag 2: sjarm-156. DOI: $10.7237 /$ sjarm/156.

Rahmawaty, Sari EK, Syofyan A, Rauf A. 2015. Integrated geographic information system and global positioning system for mapping of forest plants in supporting natural resources protection. Procedia Chem 14: 334-342.

Rahmawaty, Sitorus NA, Rauf A. 2017a. Distribution, above-ground biomass and carbon stock of the vegetation in Taman Beringin Urban Forest, Medan City, North Sumatra Indonesia. Malaysian For 80 (1): 73-84.

Rahmawaty, Patana P, Latifah S. 2017b. Spatial analysis on distribution of green belt to reduce impacts of climate change in Medan City, North Sumatra. Malaysia Appl Biol J 46 (2): 67-76.

Rahmawaty, Sembiring IEP, Batubara R, Patana P. 2018. Mapping of tree damage classification in the western part of Medan City green belts using geographic information system. IOP Conf Ser: Earth Environ Sci 166 (1): 12020. DOI: 10.1088/1755-1315/166/1/012020

Rahmawaty, Samosir JB, Batubara R, Rauf A. 2019a. Diversity and distribution of medicinal plants in the Universitas Sumatera Utara Arboretum of Deli Serdang, North Sumatra, Indonesia. Biodiversitas 20 (5): 1457-1465.

Rahmawaty, Rauf A, Frastika S. 2019b. Mapping of actual and potential land suitability for oil palm in several land unit using geographic information system. IOP Conf. Ser. Earth Environ Sci 260: 012073. DOI: $10.1088 / 1755-1315 / 260 / 1 / 012073$

Rahmawaty, Rauf A, Frastika S. 2019c. Spatial analysis for Pinus merkusii land suitability at agroforestry land in Telagah Village Sumatera Utara Indonesia. IOP Conf. Ser.: Mater. Sci. Eng. 593 012017. DOI:10.1088/1757-899X/593/1/012017

Ritung S, Nugroho K, Mulyani A, Suryani E. 2011. Technical Guidelines for Evaluating Land for Agricultural Commodities (Revised Edition). Agricultural Research and Development Agency, Bogor. [Indonesian]

Satriawan H, Harahap EM, Rahmawaty, Karim A. 2014. Land capability evaluation for agriculture in Krueng Sieumpo Watershed, Aceh. Acad Res Int 5: 55-63.

Satriawan H, Harahap EM, Rahmawaty, Karim A. 2015. Effectiveness of soil conservation to erosion control on several land-use types. Agriculture Pol'nohospodárstvo 61 (2): 61-68.

Shankar U. 2012. Effect of seed abortion and seed storage on germination and seedling growth in Aquilaria malaccensis Lamk. (Thymelaeaceae). Curr. Sci. 102: 596-604.

Shojaei S, Alipur H, Ardakani AHH, Nasab SNH, Khosravi H. 2018. Locating Astragalus hypsogeton Bunge appropriate site using AHP and GIS. Spat Inf Res 26 (2): 223-231.

Singh P, Nag A, Parmar R, Ghosh S, Bhau BS, Sharma RK. 2015. Genetic diversity and population structure of endangered Aquilaria malaccensis revealed potential for future conservation. J. Genet. 94 (4): 697-704.

Singh P, Sharma H, Nag A, Bhau BS, Sharma RK. 2015. Development and characterization of polymorphic microsatellites markers in endangered Aquilaria malaccensis. Conservation Genet Resour 7: 61.

Siah CH, Namasivayam P, Mohamed R. 2016. Transcriptome reveals senescing callus tissue of Aquilaria malaccensis, an endangered tropical tree, triggers similar response as wounding with respect to 
terpenoid biosynthesis. Tree Genetics \& Genomes 12:33 DOI $10.1007 / \mathrm{s} 11295-016-0993-\mathrm{Z}$

Soil Research Center. 2003. Technical guidelines for evaluating land for agricultural commodities. Center for Land and Agro-Climatology Research and Development, Agricultural Research and Development Agency, Bogor. [Indonesian]

Surjanto, Batubara R, Hanum TI, Pulungan W. 2019. Phytochemical and antioxidant activity of gaharu leaf tea (Aquilaria malaccensis Lamk.) as raw material of tea from middle Tapanuli Regency, North
Sumatera Province. IOP Conf Ser Earth Environ Sci 260 (2019) 012101. DOI: 10.1088/1755-1315/260/1/012101

Usuluddin, Burhanuddin, Muin A. 2018. The growth of Aquilaria malaccensis Lamk. in alluvial soils with different shade and height of seedlings. Jurnal Hutan Lestari 6 (3): 605 - 617. [Indonesian]

Wong MT, Siah CH, Faridah QZ, Mohamed R. 2013. Characterization of wound responsive genes in Aquilaria malaccensis. J. Plant Biochem. Biotechno. 22 (2): 168-175 